Environment Conservation Journal 20 (1\&2) 31-33, 2019

ISSN 0972-3099 (Print) 2278-5124 (Online)

Abstracted and Indexed

\title{
Records of predators of the green apple aphid, Aphis pomi De Geer, from Himachal Pradesh
}

\author{
Kumari M. 网
}

Received: 25.09 .2018

Revised: 28.12.2018

Accepted: 11.02.2019

\begin{abstract}
Nine species of coccinellids (Coleoptera: Coccinellidae) and three species of syrphid (Diptera: Syrphidae) predators of the green apple aphid, Aphis pomi De Geer, occurring in apple nurseries in Himachal Pradesh are reported. The coccinellids included Cheilomenes sexmaculata (F.), Coccinella septempunctata (L.), Coccinella transversalis F., Coelophora bissellata (Mulsant), Coelophora saucia (Mulsant), Harmonia dimidiata (F.), Hippodamia variegata (Goeze), Oenopia sauzeti (Mulsant) and Priscibrumus uropygialis (Mulsant), while the syrphids included Betasyrphus serarius (Wiedemann), Episyrphus balteatus De Geer and Metasyrphus confrater (Wiedemann). Of the coccinellids, C. sexmaculata, C. bissellata, C. saucia and H. dimidiata were found to be more effective for the natural suppression of A. pomi in apple nurseries in the state.
\end{abstract}

Key words: Green apple aphid (Aphis pomi), coccinellid and syrphid predators, natural suppression.

\section{Introduction}

The green apple aphid, Aphis pomi De Geer, is widely distributed in the apple growing regions of Europe, North America and India. This species has been reported to severely infest apple nursery plants in Himachal Pradesh. Studies on the biology and population dynamics of this species have revealed that large populations build up on apple seedlings in the nursery causing extensive damage to young plants in the state (Kumari and Gautam, 2004 and 2007). A number of natural enemies, including predators, parasitoids and pathogens, exist in apple nurseries which tend to suppress the aphid populations to varying extents in different regions of the world (Carroll and Hoyt, 1984; Prokopy and Croft, 1994). The natural enemy complex of A. pomi differ considerably in different apple growing regions depending upon geographic distribution and climatic conditions prevailing in the region (Carroll and Hoyt, 1984). There is, however, lack of information on the predator complex of this species in Himachal Pradesh and hence the present study was undertaken. The information so gathered will be helpful in evaluating the predatory potential of these species and for utilizing them in applied

Author's Address

Department of Zoology, Govt. Degree College Kullu, Himachal Pradesh 175101, India

E-mail.: meenakchaudhary@gmail.com biological control of this aphid pest.

\section{Materials and Method}

Regular surveys of apple nurseries at Mashobra in Shimla district and Ner Chowk in Mandi district of the state were carried out from 2003 onwards and insect species predating upon the green apple aphid were collected and maintained under laboratory conditions to study their aphidophagous behaviour.

\section{Results and Discussion}

The results revealed that A. pomi was preyed upon by a number of ladybird beetles (Coleoptera: Coccinellidae) and larvae of syrphids (Diptera: Syrphidae). These species tended to suppress the aphid populations to some extent in both the localities. The larvae and adults of the nine species of lady bird beetles found predating upon A. pomi included Cheilomenes sexmaculata (F.), Coccinella septempunctata (L.), Coccinella transversalis F., Coelophora bissellata (Mulsant), Coelophora saucia (Mulsant), Harmonia dimidiata (F.), Hippodamia variegata (Goeze), Oenopia sauzeti (Mulsant) and Priscibrumus uropygialis (Mulsant) (Table 1). Of these, C. sexmaculata, C. bissellata, $C$. saucia and $H$. dimidiata were found to show promise as effective biological 
Kumari

Table 1. Predatory complex of the green apple aphid, Aphis pomi, in Himachal Pradesh

\begin{tabular}{|c|c|}
\hline Order/ Family/ Name of the species & Developmental stage (s) recorded feeding on aphids \\
\hline \multicolumn{2}{|c|}{ Coleoptera: Coccinellidae } \\
\hline Cheilomenes sexmaculata $(\mathrm{F} .)^{*}$ & Larvae and adults \\
\hline Coccinella septempunctata $(\mathrm{L})$. & Larvae and adults \\
\hline Coccinella transversalis F. & Larvae and adults \\
\hline Coelophora bissellata Mulsant* & Larvae and adults \\
\hline Coelophora saucia $($ Mulsant)* & Larvae and adults \\
\hline Harmonia dimidiata $($ F.) & Larvae and adults \\
\hline Hippodamia variegata $($ Goeze $)$ & Larvae and adults \\
\hline Oenopia sauzeti Mulsant & Larvae and adults \\
\hline Priscibrumus uropygialis Mulsant & Larvae and adults \\
\hline Betasyrphus serarius (Wiedemann)* & Larvae \\
\hline Episyrphus balteatus De Geer* & Larvae \\
\hline Metasyrphus confrater (Wiedemann)* & Larvae \\
\hline
\end{tabular}

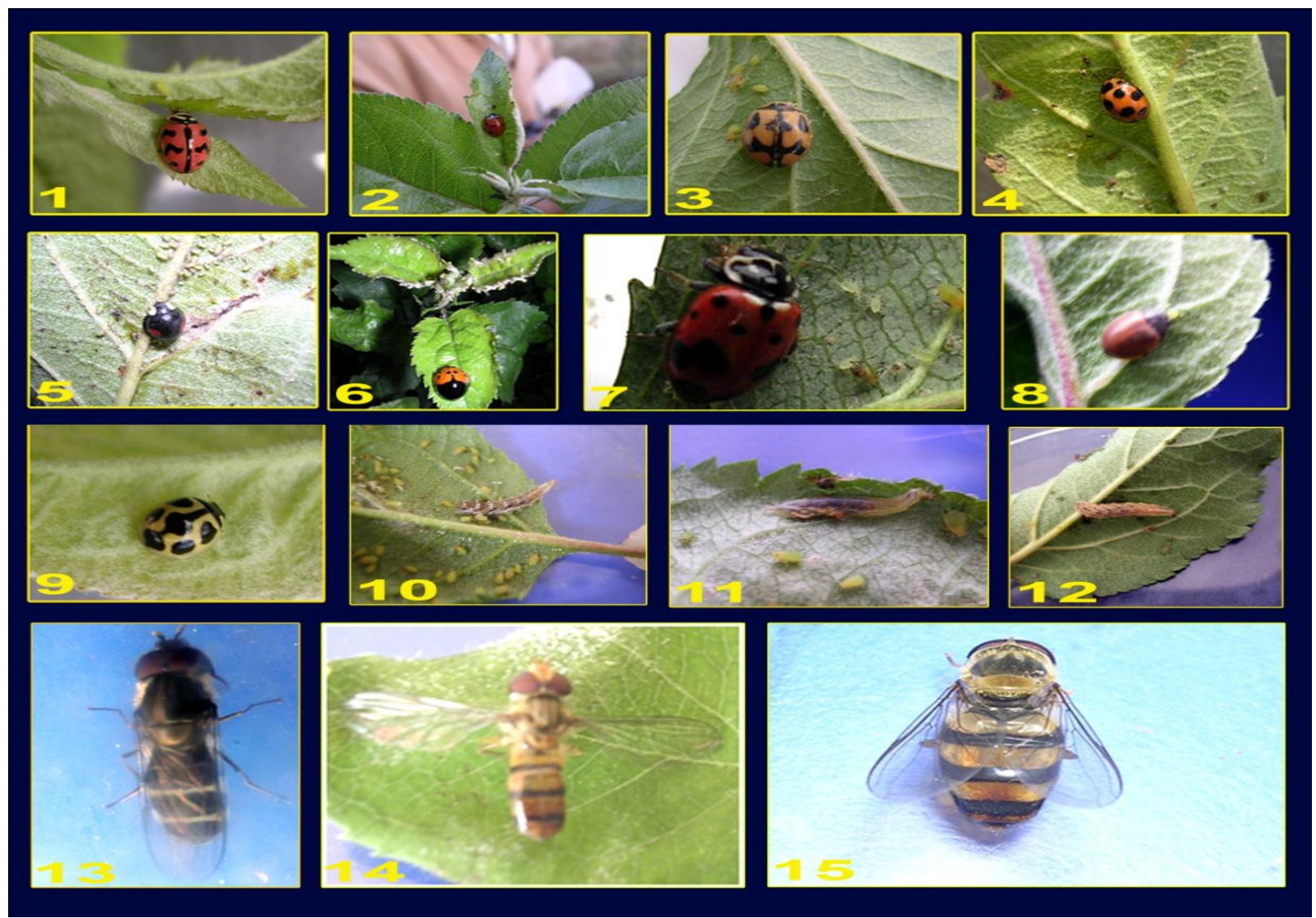

PLATE I. Efficient predators of the green apple aphid, Aphis pomi De Geer, in Himachal Pradesh 1. Adult of Cheilomenes sexmaculata (F.), 2. Adult of Coccinella septempunctata (L.), 3. Adult of Coccinella transversalis F., 4. Adult of Coelophora bissellata Mulsant, 5. Adult of Coelophora saucia (Mulsant), 6. Adult of Harmonia dimidiata (F.), 7. Adult of Hippodamia variegata (Goeze), 8. Adult of Oenopia sauzeti Mulsant, 9. Adult of Priscibrumus uropygialis (Mulsant), 10. Larva of Betasyrphus serarius (Wiedemann), 11. Larva of Episyrphus balteatus De Geer, 12. Larva of Metasyrphus confrater (Wiedemann), 13. Adult of Betasyrphus serarius, 14. Adult of Episyrphus balteatus, 15. Adult of Metasyrphus confrater 


\section{Records of predators of the green apple aphid}

control gaents of A. pomi on nursery plants of apple. The larvae of coccinellids were poor feeders in the initial instar but became voracious feeders in later instars (Kumari, 2018). Among the more important species of coccinellids, the predatory potential of $\mathrm{H}$. dimidiata larvae as well as adults was higher than that of C. sexamculata, C. bissellata and C. saucia (Kumari, 2018). The present results find support from the earlier reports of presence of eight species of ladybird beetles in apple growing areas of Washington of which Coccinella transversoguttata Faldermann, was the most abundant and voracious feeder (Carroll and Hoyt, 1984). The larvae of three species of syrphid predators, viz. Betasyrphus serarius (Wiedemann), Episyrphus balteatus De Geer and Metasyrphus confrater (Wiedemann), were found predating upon the green apple aphid in apple nurseries in both the places (Table 1). The newly hatched larvae were generally found on the lower surface of leaves where A. pomi colonies were in abundance. The syrphid larvae in the initial instars were poor feeders but became varacious feeders in the subsequent instars and consumed up to one hundred aphids per day in the final instar. The syrphid larvae thus helped in containing the early infestation of the green apple aphid and saved the nursery plants from serious damage. Syrphids have long been recognised as important predators of aphids in various crop ecosystems (Ghorpade 1981, Roy and Basu, 1977). The feeding potential of $\mathrm{M}$. confrater larvae was higher than that of E. balteatus and B. serarius (Kumari, 2006). It was also observed that the larvae of syrphid species consumed more aphids during autumn than during summer months because the life cycle of these species was longer during autumn as compared to summer (Kumari, 2006). Syrphid flies were observed hovering actively near the aphid-infested seedlings of apple and females laid eggs near the aphid colonies. This behaviour of aphidophagous syrphids was earlier reported by many workers with regard to various other aphid species (Sutherland et al., 1999; Scholz and Poehling, 2000). The effectiveness of coccinellid and syrphid predators against A. pomi indicated in this study their potential for effective suppression of this aphid pest. These naturally occurring predators could prove to be efficient tools for the management of aphid populations if suitable techniques for rearing them under laboratory conditions were developed, ensuring their availability throughout the year. This will reduce the load of excessive use of pesticides.

\section{Acknowledgements}

The author is thankful to Dr J Poorani, Project Directorate of Biological Control, Bengaluru, Karnataka for the identification of ladybird beetles and Dr K C Sharma, Dr Y S Parmar University of Horticulture and Forestry, Solan, Himachal Pradesh for identification of syrphid flies.

\section{References}

Carroll, D. P. and Hoyt. S. C. 1984. Natural enemies and their effects on apple aphid, Aphis pomi De Geer (Homoptera: Aphididae), colonies on young apple tree in central Washington. Environmental Entomology, 13: 469-81.

Ghorpade, K. D. 1981. Insect prey of Syrphidae (Diptera) from India and neighbouring countries: a review and bibliography. Tropical Pest Management, 27: 62-82.

Kumari, M. 2006. Studies on biology, cytogenetics and biological control of green apple aphid, Aphis pomi De Geer. Ph.D. Thesis in Life Sciences (Zoology), Himachal Pradesh University, Shimla.: 162.

Kumari, M. and Gautam, D. C. 2004. Biology of green apple aphid, Aphis pomi De Geer on apple host. Indian Journal of Hoticulture 61: 229-31.

Kumari, M. and Gautam, D. C. 2007. Studies on the morphs, life history and behaviour of green apple aphid, Aphis pomi De Geer on apple host in India. Polish. Journal of Entomology 76: 119-41.

Kumari, M. 2018. Studies on the biology and predatory potential of Harmonia dimidiata, a major predators of Aphis pomi De Geer on apple host in India. Advances in Entomology, 6: 170-175.

Prokopy, R. J. and Croft, B. A. 1994. Apple pest management, pp.743-759. Introduction to Pest Management,. R L Metcalf R L and W H Luckmann (eds.). John Wiley \& Sons, New York: 650.

Roy, P. and Basu, S. K. 1977. Bionomics of aphidopagous syrhphid flies. Indian Journal of Entomology 39: 165-74.

Scholz, D. and Poehling, H. M. 2000. Oviposition site selection of Episyrphus balteatus. Entomologia Experimentalis et Applicata 94: 149-58.

Sutherland, J. P., Sullivan, M. S. and Poppy, G. M. 1999. The influence of floral character on the foraging behaviour of the hoverfly, Episyrphus balteatus (De Geer) (Diptera; Syrphidae). Entomologia Experimentalis et Applicata 93: 157-64. 